\title{
EFEKTIFITAS PAPARAN SINAR UV DAN ALKOHOL 70\% TERHADAP TOTAL BAKTERI PADA UANG KERTAS YANG BEREDAR DI MASA PANDEMI COVID-19
}

\author{
Alinea Dwi Elisanti ${ }^{1}$, Efri Tri Ardianto $^{2}$, Novita Cholifah Ida $^{3}$, Eryk Hendriatno ${ }^{4}$ \\ ${ }^{1,2}$ Jurusan Kesehatan, Politeknik Negeri Jember \\ ${ }^{3}$ Laboratorium Biosain, Politeknik Negeri Jember \\ ${ }^{4}$ Puslitbang Stem Cell, Universitas Airlangga Surabaya
}

Email korespondensi : $\underline{\text { alinea@polije.ac.id }}$

\begin{abstract}
ABSTRAK
Corona Virus Disease (COVID-19) telah menjadi pandemi global dunia. Indonesia telah menetapkan pandemi ini sebagai bencana nasional. Tercatat kasus positif dan kematian yang mengalami peningkatan setiap hari. Hal ini menjadi daftar panjang dampak pandemi COVID-19 bagi kehidupan. Beberapa solusi telah di rancang untuk mencegah cepatnya penularan virus ini, salah satunya dengan membuat produk sterilisator dan hand sanitizer. Namun masih terdapat perdebatan terkait efektifitas penggunaan sinar UV dan antiseptik sebagai bahan produk kebersihan yang ditawarkan. Penelitian ini bertujuan untuk mengetahui efektifitas paparan sinar UV dan pemakaian antiseptik untuk membunuh kuman. Penelitian ini menggunakan desain eksperimen, sampel yang digunakan berupa uang kertas yang diambil bakterinya dan ditumbuhkan pada media agar yang di klasifikasikan menjadi 3 kelompok yaitu tanpa perlakuan, perlakuan alkohol $70 \%$ dan perlakuan sinar UV. Sampel dianalisis menggunakan metode dilution agar dan swab test dengan dua kali pengulangan. Hasil penelitian menunjukkan rata-rata jumlah colony forming unit (cfu) bakteri menggunakan metode dilution test dan swab test menunjukkan 419 cfu pada kelompok tanpa perlakuan; $4 \mathrm{cfu}$ pada perlakuan alkohol $70 \%$ dan $150 \mathrm{cfu}$ pada perlakuan sinar UV (10 detik). Dari hasil uji tersebut diketahui bahwa alkohol 70\% lebih efektif dibandingkan dengan pemaparan sinar UV 10 detik untuk mengurangi jumlah cfu bakteri pada uang kertas.
\end{abstract}

Kata kunci : alkohol, dilution agar, uang kertas, sinar UV, swab test 


\title{
EFFECTIVENESS OF UV AND ALCOHOL 70\% EXPOSURE TO TOTAL BACTERIA OF FOLDING MONEY CIRCULATING DURING THE PANDEMIC COVID-19
}

\begin{abstract}
Corona virus disease (COVID-19) has become a global pandemic in the world. Indonesia has declared this pandemic as a national disaster. Positive cases and deaths have increased every day. This was a long list of the effects of the COVID-19 pandemic on life. Several solutions have been designed to prevent the rapid transmission of this virus, one of them was by making sterilizer and hand sanitizer products. But there was still debate regarding the effectiveness of the use of $U V$ rays and antiseptics as hygiene products offered. This study want to determine the effectiveness of UV exposure and the use of antiseptics to kill germs. This study used an experimental design, the sample used was in the form of folding money taken by the bacteria and grown on the media so that were classified into 3 groups, namely without treatment, 70\% alcohol treatment and 10 seconds UV light treatment. The samples were analyzed using the dilution agar method and swab test with two repetitions. The results showed the average number of colony forming units (cfu) of bacteria using the dilution test method and swab test methode were 419 cfu on without treatment group; 4 cfu on alcohol $70 \%$; and 150 cfu on UV light (10 seconds). The alcohol 70\% was more effective than 10 seconds UV light exposure to reduce the amount of bacterial cfu on folding money.
\end{abstract}

Keywords : Alcohol; Dilution Agar; Folding Money; UV light; Swab test.

\section{PENDAHULUAN}

Corona Virus Disease (COVID19) telah menjadi pandemi global dunia dan dinyatakan sebagai bencana nasional di Indonesia. Gugus Tugas Covid Republik Indonesia per 19 April 2020 melaporkan terdapat 6575 kasus terkonfirmasi dan mengalami peningkatan sebesar 5,23\% dibandingkan hari sebelumnya, terdapat 5307 orang dalam perawatan (kenaikan sebesar $5,55 \%$ dibanding hari sebelumnya), terlapor 582 orang meninggal (mengalami kenaikan sebesar 8,79\% dibanding hari sebelumnya), dan sembuh mencapai
686 orang (Gugus Tugas Covid19, 2020a). Dimana WHO melaporkan bahwa case fatality rate (CFR) atau tingkat kematian kasus covid-19 di Indonesia mencapai 8,3\% adalah dua kali lipat CFR dunia (news detik.com, 2020).

Peningkatan prevalensi kasus covid-19 yang signifikan, mendorong pemerintah melakukan kebijakan social distancing (pembatasan kegiatan sosial), physical distancing (pembatasan kontak fisik), bahkan beberapa daerah sudah menerapkan kebijakan Pembatasan Sosial Berskala Besar (PSBB) (Gugus Tugas Covid19, 2020b). 
Anjuran terkait personal higiene yang seharusnya dimulai dari tingkat individu yaitu anjuran untuk sering melakukan Cuci Tangan Pakai Sabun (CTPS) (Ardianto et al., 2017), stay at home dan penggunaan masker saat keluar rumah terus di gaungkan oleh pemerintah. Hal ini tentunya memberi dampak pada peningkatan permintaan pada kebutuhan bahan pembersih rumah tangga, terutama sabun cuci tangan. Sabun dipercaya menjadi bahan yang mampu membunuh virus dengan cara memecah protein pada virus SARS COV 2, sehingga sabun menjadi sangat vital untuk memutus mata rantai penularan COVID-19.

Namun praktik CTPS tidak bisa dilakukan pada kondisi tertentu, sehingga muncul beberapa inovasi untuk menggantikan fungsi CTPS yaitu produk sterilisasi dan hand sanitizer. Beberapa produk sterilisasi baik dari dalam maupun luar negeri banyak yang memanfaatkan sinar UV, sebagian produsen mengklaim bahwa sinar UV mampu menghalau virus dan bakteri.

Sebagai contoh produk sterilisator tangan yang dijual di marketplace yang mengklaim mampu membunuh virus, kuman dan bakteri 99,9\%, ada juga produk sterilisator berbasis UV mengklaim produknya mampu membunuh kuman dan bakteri pada peralatan sebesar $\quad 99.99 \%$ (Kumparan.com, 2020) dan (Shopee.co.id, 2020).

Sinar ultraviolet (UV) merupakan salah satu sinar yang memiliki daya radiasi yang bersifat letal bagi organisme. Karena bersifat letal, maka radiasi UV sering digunakan pada tempat yang memiliki kondisi aseptik. Sinar UV memiliki panjang gelombang mulai $4 \mathrm{~nm}$ hingga $400 \mathrm{~nm}$, sedangkan efisiensi tertinggi untuk mengendalikan mikroorganisme yaitu pada titik panjang gelombang $365 \mathrm{~nm}$. Sinar UV memiliki daya penetrasi yang sangat rendah, selapis kaca yang tipis diibaratkan mampu menahan sebagian besar sinar UV, sehingga sinar UV hanya efektif untuk mengendalikan mikroorganisme pada permukaan yang terpapar langsung atau berada pada permukaan medium yang transparan terhadap sinar UV. Penyerapan maksimal sinar UV di dalam sel mirkoorganisme terjadi pada asam nukleat, sehingga di duga mekanisme perusakan sel oleh sinar UV terjadi pada ribosom, hal ini yang menyebabkan terjadinya mutasi atau kematian sel (Ariyadi \& Sinto Dewi, 2009).

Bahan lain yang sering digunakan sebagai antiseptik dan terbukti aman adalah alkohol. Alkohol juga merupakan bahan dasar produk sterilisasi utama, hasil penelitian menunjukkan bahwa alkohol $70 \%$ terbukti mampu mencegah infeksi pada tali pusat bayi baru lahir (Yunanto et al., 2005). Hasil penelitian lain menunjukkan larutan alkohol $70 \%$ yang sudah dipakai selama 1 hari memiliki zona hambat bakteri sebesar 3,88 mm (baik) (Silakhudin \& Fatmawati, 2015).

Transmisi virus SARS COV-2 yang menyebabkan COVID-19 bisa melalui beberapa hal, salah satunya adalah melalui tangan yang memegang barang dan benda yang terkontaminasi virus. Salah satu barang yang menjadi perantara adalah uang, baik uang kertas 
maupun logam. Namun saat ini masih belum pernah dikaji apakah uang bisa menjadi penyebab penularan, untuk itu penelitian ini bertujuan untuk mengkaji efektifitas pemaparan sinar UV yang masih menjadi kontradiksi dan alkohol $70 \%$ sebagai bahan yang sering digunakan terhadap jumlah bakteri pada uang kertas di masa pandemi COVID19.

\section{METODE PENELITIAN}

ALAT

Peralatan yang digunakan dalam penelitian ini adalah cawan peditrish, falcon tube, L glass, autoklave, laminar air flow, inkubator, dan lampu UV, cotton swab.

\section{Bahan}

Sedangkan bahan yang digunakan meliputi alkohol 70\%, media NA (Nutrient Agar), garfis $\mathrm{NaCl} 0,85 \%$, Media NB (Nutrient Broth), pepton water (larutan attraktan).

\section{Metode}

Penelitian ini menggunakan desain eksperimen. Menggunakan 3 (tiga) kelompok sampel yang diamati. Berikut ini rancangan penelitian yang digunakan.

Tabel 1. Rancangan Penelitian

\begin{tabular}{|c|c|c|c|c|}
\hline \multirow[t]{2}{*}{ No } & \multirow[t]{2}{*}{ Perlakuan } & \multicolumn{2}{|c|}{ Ulangan } & \multirow[t]{2}{*}{ Rerata } \\
\hline & & 1 & 2 & \\
\hline 1 & Tanpa Perlakuan (A) & A1 & $\mathrm{A} 2$ & $\mathrm{~A} 1+\mathrm{A} 2 / 2$ \\
\hline 2 & Alkohol 70\% (B) & B1 & B2 & $\mathrm{B} 1+\mathrm{B} 2 / 2$ \\
\hline 3 & Sinar UV (10 detik) (C) & $\mathrm{C} 1$ & $\mathrm{C} 2$ & $\mathrm{C} 1+\mathrm{C} 2 / 2$ \\
\hline
\end{tabular}

\section{Sampel Penelitian}

Sampel penelitian ini berupa uang kertas, yang diambil bakterinya dan ditumbuhkan pada media agar yang di klasifikasikan menjadi 3 kelompok yaitu tanpa perlakuan, perlakuan alkohol $70 \%$ dan perlakuan sinar UV. Pemaparan sinar UV dilakukan menggunakan lampu UV 11 watt selama 10 detik dengan jarak paparan $30 \mathrm{~cm}$.

\section{Prosedur Penelitian}

Prosedur penelitian ini terdiri dari dua teknik, yaitu teknik pengulasan (swab test) dan teknik pengenceran berseri (dilution test).

\section{Teknik Pengulasan ( $S w a b$ )}

Teknik ini bertujuan untuk memindahkan mikroba yang berada di permukaan sampel yang memiliki permukaan luas dan pada umumnya sulit dipindahkan dengan menggunakan cottons swab/cotton bud. Teknik ini dilakukan dengan mengusapkan cotton bud memutar sehingga seluruh permukaan kapas dari cotton bud kontak dengan permukaan sampel. Hasil ulasan akan lebih baik jika cotton bud dicelupkan terlebih dahulu ke dalam larutan attraktan (contoh pepton water). 


\section{Gambar 1. Teknik Pengulasan (Swab Test)}

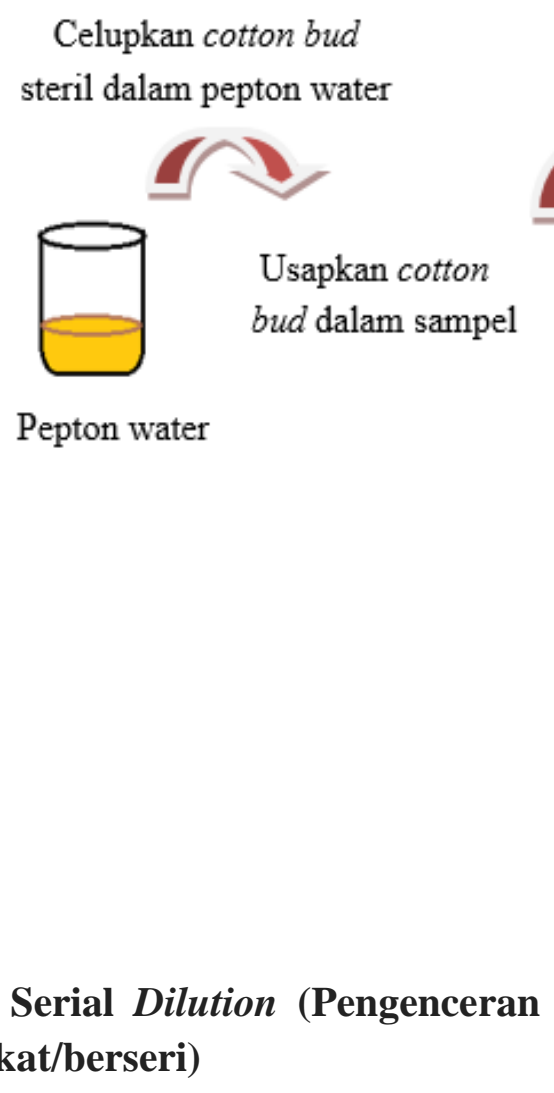

Teknik Serial Dilution (Pengenceran bertingkat/berseri)

\author{
Tujuan dari pengenceran
bertingkat yaitu memperkecil atau \\ Tujuan dari pengenceran
bertingkat yaitu memperkecil atau \\ mengurangi jumlah mikroba yang \\ tersuspensi dalam cairan. Penentuan \\ besarnya atau banyaknya tingkat
}

Usapkan cotton bud yang berisi sampel pada permukaan

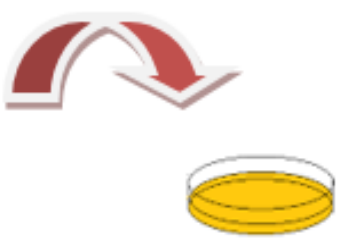

NA (Nutrient Agar)@25 ml/Petridish

Inkubasi $37^{\circ} \mathrm{C}, 24$ hours

Perhitungan Total Bakteri pengenceran tergantung kepada perkiraan jumlah mikroba dalam sampel. Digunakan perbandingan $1: 9$ untuk sampel dan pengenceran pertama dan selanjutnya, sehingga pengenceran berikutnya mengandung $1 / 10$ sel mikroorganisme dari pengenceran sebelumnya 


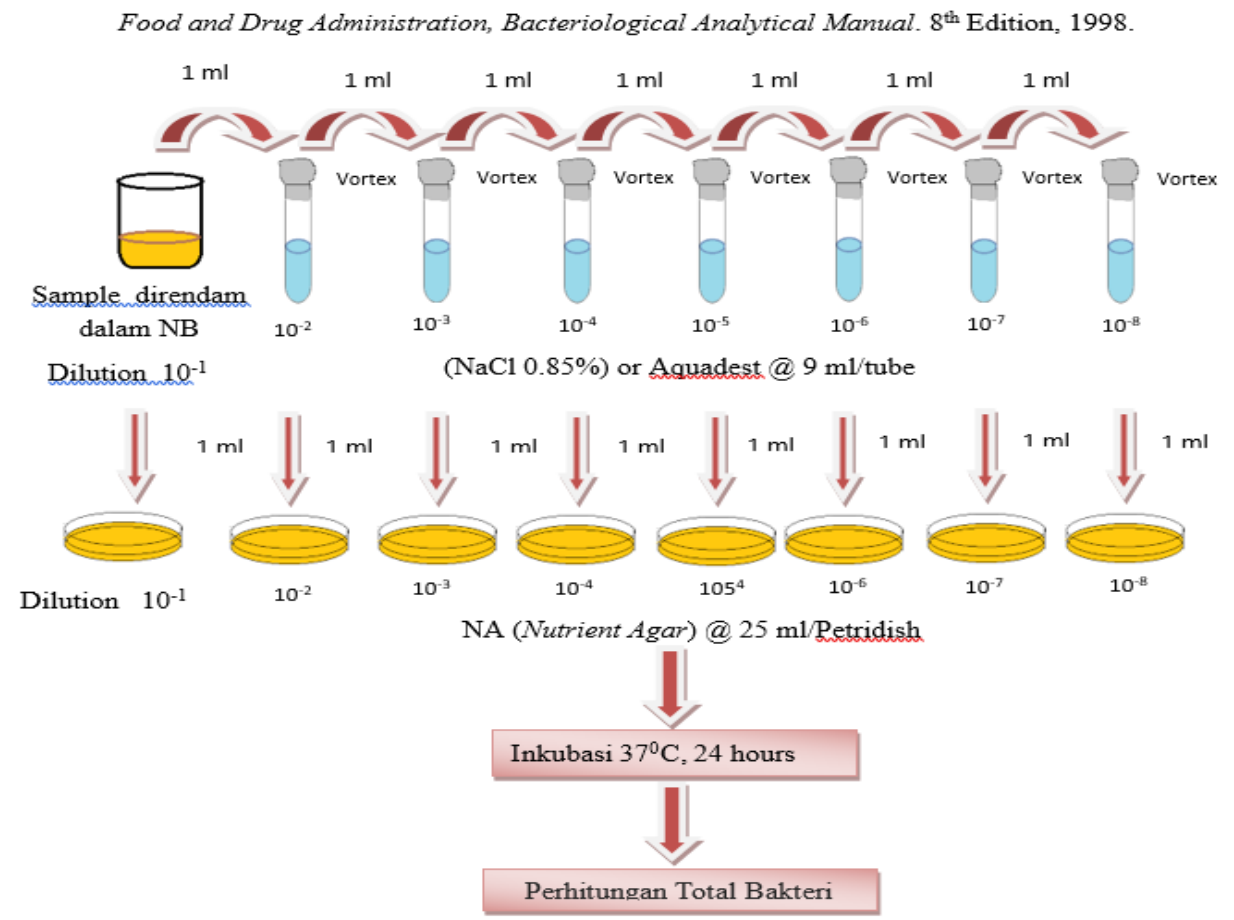

Gambar 2. Teknik Serial Dilution (Pengenceran Bertingkat)

\section{HASIL DAN PEMBAHASAN}

Hasil dan bahasan pada penelitian ini berkaitan dengan maraknya isu terkait penularan virus SARS COV-2 melalui media uang kertas yang beredar dimasyarakat. Hasil studi yang telah dilakukan pada virus corona jenis Severe Acute Respiratory Syndrome (SARS) melaporkan bahwa virus corona dapat hidup hingga 72 jam pada kertas (Kompas.com, 2020). Berdasarkan kesamaan struktural di antara berbagai jenis virus corona, masuk akal bila hal ini berlaku pula pada jenis COVID-19.

Penularan kemungkinan bisa terjadi jika seseorang menyentuh permukaan uang kertas, kemudian langsung menyentuh mata, hidung, atau mulut, tanpa mencuci tangan dengan air mengalir dan sabun terlebih dahulu, hal itu dapat membiarkan virus masuk ke dalam tubuh. Sehingga diperlukan studi lebih lanjut terkait teknik sterilisasi yang bisa digunakan untuk uang kertas yang beredar agar terhindar dari kuman termasuk di dalamnya adalah bakteri dan virus. Namun dalam riset ini identifikasi masih dilakukan terbatas pada jumlah bakteri yang ada di uang kertas.

Hasil penelitian dalam penelitian ini disajikan dalam tabel 2 dan 3 berikut ini.

Tabel 2. Jumlah Total Bakteri Metode Dilution Test. 


\begin{tabular}{lcccc}
\hline & Sampel & $\begin{array}{c}\text { Jumlah } \\
\text { Koloni }\end{array}$ & $\begin{array}{c}\text { Jumlah } \\
\text { rerata (cfu) }\end{array}$ & $\begin{array}{c}\text { Rerata } \\
\text { Jumlah (cfu) }\end{array}$ \\
\hline $\begin{array}{l}\text { Tanpa } \\
\begin{array}{l}\text { Perlakuan } \\
\text { (Kontrol) }\end{array}\end{array}$ & Ulangan 1 & 141 & $4,09 \mathrm{E}+02$ & 419 \\
\hline Alkohol 70\% & Ulangan 2 & 136 & $4,30 \mathrm{E}+02$ & \\
& & 4 & $4,00 \mathrm{E}+00$ & 4 \\
\hline $\begin{array}{l}\text { Sinar UV } \\
\text { detik) }\end{array}$ & Ulangan 2 & 4 & $4,00 \mathrm{E}+00$ & \\
& Ulangan 1 & 147 & $1,51 \mathrm{E}+02$ & 150 \\
& & 148 & $1,48 \mathrm{E}+02$ & \\
\hline
\end{tabular}

Tabel 3. Jumlah Total Bakteri Metode Swab Test.

\begin{tabular}{lccc}
\hline Perlakuan & Jumlah Bakteri & $\begin{array}{l}\text { Jumlah } \\
\text { rata-rata }\end{array}$ & Bakteri \\
& Ulangan 1 & Ulangan 2 & \\
\hline Tanpa perlakuan (kontrol) & 420 & 418 & 419 \\
Alkohol 70\% & 4 & 5 & 4 \\
Sinar UV (10 detik) & 152 & 148 & 150 \\
\hline
\end{tabular}

Tabel 2 dan 3 menunjukkan total bakteri pada masing-masing kelompok perlakuan dan kelompok kontrol memperoleh hasil yang sama. Paparan sinar UV selama 10 detik diketahui mampu mengurangi jumlah bakteri sebesar $64,21 \%$ jika dibandingkan dengan kelompok kontrol (tanpa perlakuan).

Hasil temuan ini sejalan dengan penelitian yang dilakukan oleh Ariyadi, dkk yang melakukan pengujian berupa penyinaran UV 38 watt selama 1 menit, dengan jarak $45 \mathrm{~cm}$ pada media NA yang mengandung bakteri Bacillus sp (adalah bakteri kontaminan) di dapatkan koloni sebanyak 18 buah, penyinaran selama 5 menit didapatkan jumlah koloni 5 buah dan penyinaran 10 menit tidak ada koloni yang tumbuh. Jika dibandingkan dengan media kontrol yang tidak di beri paparan sinar UV diketahui terjadi pertumbuhan koloni yang sangat penuh atau tidak dapat dihitung (Ariyadi \& Sinto Dewi, 2009).

Total bakteri pada kelompok perlakuan alkohol $70 \%$ diketahui berkurang sebesar 99,05\% jika dibandingkan dengan kelompok kontrol (tanpa perlakuan). Larutan antiseptik berbahan dasar alkohol kombinasi antara Chlorhexidine gluconate Povidone iodine 10\%(CP3) dan Chlorhexidine gluconate - Alkohol 70\% - Povidone iodine 10\%(CAP3) terbukti efektif untuk menurunkan jumlah koloni 
kuman pada kulit medan operasi fraktur tertutup elektif (Purnomo, 2010).

Penggunaan alkohol $70 \%$ tidak bisa menghilangkan seluruh bakteri pada uang kertas (100\%), hal ini sejalan dengan hasil penelitian tentang efektivitas sterilisasi menggunakan alkohol $70 \%$, otoklaf, infra merah dan ozon terhadap pertumbuhan bakteri berspora bacillus subtilis yang pernah di lakukan oleh Adji dkk (Adji et al., 2007).

Perbandingan beberapa metode sterilisasi tersebut menunjukkan bahwa penggunaan alkohol $70 \%$ selama 3 jam belum mampu mencegah tumbuhnya bakteri bacillus subtilis (Adji et al., 2007). Fakta ini diperkuat oleh penelitian lain yang menyebutkan bahwa Alkohol 70\% belum mampu menghambat pertumbuhan beberapa bakteri dipengaruhi oleh lama waktu penggunaan alkohol, dimana larutan alkohol $70 \%$ yang baru saja digunakan lebih efektif dibandingkan dengan larutan alkohol $70 \%$ yang digunakan selama 1 hari dan larutan alkohol yang sudah digunakan selama 5 hari dengan tingkat signifikansi 0,02 (Silakhudin \& Fatmawati, 2015).

\section{SIMPULAN}

Paparan sinar UV selama 10 detik memberikan efektivitas sebesar $64,21 \%$ terhadap penurunan jumlah bakteri pada uang kertas yang beredar di masyarakat pada masa pandemi COVID-19, sedangkan penggunaan alkohol $70 \%$ memberikan efektivitas yang lebih tinggi yaitu mencapai $99,05 \%$.

\section{UCAPAN TERIMAKASIH}

Terimakasih saya ucapkan kepada laboratorium biosain Politeknik Negeri Jember yang telah memberikan subsidi dalam proses penelitian.

\section{DAFTAR PUSTAKA}

Adji, D., Zuliyanti, \& Larashantyz, H. (2007). Perbandingan Efektivitas Sterilisas I Alkohol 70\%, Inframerah, Otoklaf Dan Ozon Terhadap Pertumbuhan Bakteri Bacillus Subtilis. Jurnal Sain Vet, 25(1), 17-24.

Ardianto, E. T., Setiawan, D. P. H., \& Permana, A. (2017). Penyuluhan Kesehatan dan Praktik CTPS \& PHBS Pada Siswa di Madrasah Ibtidaiyah Al- Badri Kecamatan Kalisat Kabupaten Jember. 126129.

Ariyadi, T., \& Sinto Dewi, S. (2009).

Pengaruh Sinar Ultra Violet

Terhadap Pertumbuhan Bakteri

Bacillus sp. Sebagai Bakteri

Kontaminan. Jurnal Kesehatan, 2(2), 20-25.

Gugus Tugas Covid19. (2020a).

Beranda | Gugus Tugas

Percepatan Penanganan COVID-

19. https://covid19.go.id/

Gugus Tugas Covid19. (2020b).

Pemerintah Persilakan Daerah

Ajukan PSBB - Berita Terkini |

Gugus Tugas Percepatan

Penanganan COVID-19.

https://covid19.go.id/p/berita/peme rintah-persilakan-daerah-ajukanpsbb

Kumparan.com. (2020). UV Sterilizer?

Mari Kenali Manfaat dan Kegunaannya - kumparan.com. 
https://kumparan.com/babyologist/ uv-sterilizer-mari-kenali-manfaatdan-kegunaannya27431110790553290

News detik.com. (2020). Tingkat Kematian Pasien Corona di RI 8,3\%, 2 Kali Lipat Rata-rata Dunia.

https://news.detik.com/berita/d4944494/tingkat-kematian-pasiencorona-di-ri-83-2-kali-lipat-ratarata-dunia

Purnomo, W. (2010). Perbandingan Efektivitas Kombinasi

Chlorhexidine Gluconate Cetrimide-Alkohol 70\%-Povidone Iodine 10\% dengan Chlorhexidine Gluconate Cetrimide - Povidone Iodine 10\% Sebagai Antiseptik Terhadap Penurunan Kepadatan Kuman pada Operasi Fraktur Tertutup Elekti [UNS (Sebelas Maret University)]. https://digilib.uns.ac.id/dokumen/d etail/16793/Perbandinganefektivitas-kombinasichlorhexidine-gluconate-cetrimidealkohol-70-povidone-iodine-10- dengan-chlorhexidine-gluconatecetrimide-povidone-iodine-10sebagai-antiseptik-terhadappenurunan-kepadatan-k

Shopee.co.id. (2020). Alat Sterilisasi Sinar UV Portable Multifungsi dengan Lampu UV | Shopee Indonesia.

https://shopee.co.id/Alat-

Sterilisasi-Sinar-UV-Portable-

Multifungsi-dengan-Lampu-UV-

i.129753091.2797635686

Silakhudin, A. R., \& Fatmawati, D. (2015). Affectivity of Repeatly Used Alcohol towards Inhibition of Bacteria Streptococcus mutans. In Jurnal Riset Kesehatan (Vol. 4, Issue 3).

Yunanto, A., Hartoyo, E., \& Budiarti, L. Y. (2005). Peran Alkohol 70\%, Povidon-Iodine $10 \%$ dan Kasa Kering Steril dalam Pencegahan Infeksi pada Perawatan Tali Pusat. Sari Pediatri, 7(2), 58-62. 